\title{
Blocking effect of colloids on arsenate adsorption during co-transport through saturated sand columns ${ }^{\text {मे }}$
}

\author{
Jie Ma ${ }^{\text {a, b, c }}$, Huaming Guo a, b, *, Mei Lei ${ }^{c}$, Xiaoming Wan ${ }^{c}$, Hanzhi Zhang ${ }^{\mathrm{d}}$, \\ Xiaojuan Feng ${ }^{c}$, Rongfei Wei ${ }^{c}$, Liyan Tian ${ }^{c}$, Xiaokun Han ${ }^{c}$ \\ a State Key Laboratory of Biogeology and Environmental Geology, China University of Geosciences, Beijing 100083, PR China \\ b School of Water Resources and Environment, China University of Geosciences (Beijing), Beijing 100083, PR China \\ ${ }^{c}$ Center for Environmental Remediation, Institute of Geographic Sciences and Natural Resources Research, Chinese Academy of Sciences, Beijing 100101, PR \\ China \\ d Shenyang Academy of Environmental Sciences, Shenyang 110016, PR China
}

\section{A R T I C L E I N F O}

\section{Article history:}

Received 15 December 2015

Received in revised form

24 February 2016

Accepted 4 March 2016

Available online 25 March 2016

\section{Keywords:}

Soil colloids

Strong repulsion

Arsenate

Low adsorption

Co-transport

Blocking effect

\begin{abstract}
A B S T R A C T
Transport of environmental pollutants through porous media is influenced by colloids. Co-transport of $\mathrm{As}(\mathrm{V})$ and soil colloids at different $\mathrm{pH}$ were systematically investigated by monitoring breakthrough curves (BTCs) in saturated sand columns. A solute transport model was applied to characterize transport and retention sites of $A s(V)$ in saturated sand in the presence of soil colloids. A colloid transport model and the DLVO theory were used to reveal the mechanism and hypothesis of soil colloid-promoted $\mathrm{As}(\mathrm{V})$ transport in the columns. Results showed that rapid transport of soil colloids, regulated by $\mathrm{pH}$ and ionic strength, promoted $\mathrm{As}(\mathrm{V})$ transport by blocking $\mathrm{As}(\mathrm{V})$ adsorption onto sand, although soil colloids had low adsorption for $\operatorname{As}(\mathrm{V})$. The promoted transport was more significant at higher concentrations of soil colloids (between $25 \mathrm{mg} \mathrm{L}^{-1}$ and $150 \mathrm{mg} \mathrm{L}^{-1}$ ) due to greater blocking effect on $\mathrm{As}(\mathrm{V})$ adsorption onto the sand surfaces. The blocking effect of colloids was explained by the decreases in both instantaneous (equilibrium) As adsorption and first-order kinetic As adsorption on the sand surface sites. The discovery of this blocking effect improves our understanding of colloid-promoted As transport in saturated porous media, which provides new insights into role of colloids, especially colloids with low As adsorption capacity, in As transport and mobilization in soil-groundwater systems.
\end{abstract}

(C) 2016 Elsevier Ltd. All rights reserved.

\section{Introduction}

Colloidal particles are found in virtually all natural waters, including surface waters, soil pore waters, and groundwater systems (Bauer and Blodau, 2009; Kretzschmar and Schafer, 2005). Previous studies have indicated that the transport of pollutants (e.g., heavy metals, radioactive pollutants, and organic matter) through subsurface environments is facilitated by colloids (Denaix et al., 2001; Hammes et al., 2013; Honeyman, 1999; Kersting et al., 1999; Pedrot et al., 2008; Roy and Dzombak, 1997; Wang et al., 2011a; Yin et al., 2010; Zhang et al., 2005). The generally accepted mechanism of colloid-facilitated pollutant transport was that the

\footnotetext{
This paper has been recommended for acceptance by B. Nowack.

* Corresponding author. School of Water Resources and Environment, China University of Geosciences (Beijing), Beijing 100083, PR China.

E-mail address: hmguo@cugb.edu.cn (H. Guo).
}

colloid acts as a carrier to adsorb the pollutant and thus promote pollutant transport (Kanti Sen and Khilar, 2006).

To investigate the fate of colloid-associated pollutants, various three-phase transport models (Simunek et al., 2006), including the nonreactive colloids with the solid phase model, the first-order kinetic attachment of colloids model, the irreversible nonlinear kinetic attachment of colloids model, and the Langmuir kinetics attachment of colloids model, have been developed to delineate the pollutant transport in the presence of colloids (Grolimund and Borkovec, 2005; Grolimund et al., 1996; Saiers, 2002; Saiers and Hornberger, 1996; Simunek et al., 2006; Zou and Zheng, 2013). A model, only considering the colloid as a carrier, simulated kaolinite colloid-facilitated ${ }^{137} \mathrm{Cs}$ transport, but calculated data greatly deviated from the observed data obtained in experiments (Saiers and Hornberger, 1996). The adsorption of ${ }^{137} \mathrm{Cs}$ on kaolinite colloids is low, but the colloids greatly facilitate ${ }^{137} \mathrm{Cs}$ transport in the initial stage of breakthrough (Saiers and Hornberger, 1996). Unfortunately, little attention has been paid to this issue. Since most of 
studies used colloids with a high adsorption capacity for pollutants during experiments (Grolimund and Borkovec, 2005; Grolimund et al., 1996; Saiers, 2002; Wang et al., 2011a, 2014), colloids mainly acted as carriers to facilitate the pollutant transport. Among them, ferruginous colloids (e.g., ferrihydrite colloids, Fe(III)hydroxysulfates colloids, and Fe-NOM colloids) with a high adsorption capacity have been utilized to investigate facilitated As transport (Fritzsche et al., 2011; Guo et al., 2011; Neubauer et al., 2013; Slowey et al., 2007). Few similar phenomena were observed.

As the most common colloids in environment, soil colloids are composed of mineral colloids (phyllosilicate minerals containing Fe and $\mathrm{Al}$ oxides and amorphous minerals), organic colloids, and organo-mineral complexes colloids (Kretzschmar and Schafer, 2005). Similar to ${ }^{137} \mathrm{Cs}$ adsorbed onto kaolinite colloids, As adsorption onto soil colloids is relatively lower due to the limited effective adsorption sites of the colloid compared with those of the ferruginous colloids (Dousova et al., 2012). However, it is still unknown how soil colloid facilitate As transport.

Both soil colloid and As transport, especially $\mathrm{As}(\mathrm{V})$, in porous media are pH-dependent. Iron(III) (hydr)oxides, the main Asbearing minerals in porous media and soil colloid, are predominantly positively charged at $\mathrm{pH}$ 3.0-7.0 and negatively charged at pH 8.0-10.0 (Guo et al., 2014). Because $\mathrm{As}(\mathrm{V})$ is predominantly present as oxyanions $\left(\mathrm{H}_{2} \mathrm{AsO}_{4}^{-}\right.$and $\left.\mathrm{HAsO}_{4}^{2-}\right)$ under $\mathrm{pH}>4.0$, the increase in $\mathrm{pH}$ to $>8.2$ drastically decreases $\mathrm{As}(\mathrm{V})$ adsorption onto $\mathrm{Fe}(\mathrm{III})$ (hydr)oxides (Qiao et al., 2012) due to the electrostatic repulsion, and thus promote $A s(\mathrm{~V})$ transport in porous media and $\operatorname{As}(\mathrm{V})$ desorption from soil colloid. Therefore, soil colloid-associated $\mathrm{As}(\mathrm{V})$ transport would be dependent on $\mathrm{pH}$. The variation of charge led to change of zeta potential. Negative zeta potentials of soil colloid and sand decrease with decreasing $\mathrm{pH}$. Therefore, low $\mathrm{pH}$ promotes colloid deposition, which attributes to the decrease in repulsive interaction energies between colloids and grain surfaces (Wan and Tokunaga, 2002). In contrast, high pH enhances colloid transport due to the increased repulsive forces (Ryan and Elimelech, 1996).

The purpose of this study is to systematically investigate cotransport of soil colloids and $\mathrm{As}(\mathrm{V})$ at different $\mathrm{pH}$ in saturated sand columns. The effect of soil colloids and their concentrations on $\mathrm{As}(\mathrm{V})$ transport at different $\mathrm{pH}$ was assessed by monitoring breakthrough curves (BTCs). In addition, a solute transport model (Cameron and Klute, 1977; Selim et al., 1976) was used to simulate $\mathrm{As}(\mathrm{V})$ transport and evaluate retention sites of sand, and $\mathrm{As}(\mathrm{V})$ transport mechanisms in the presence of soil colloids were revealed with colloid transport model (Bradford et al., 2003) and DLVO theory (Derjaguin and Landau, 1941; Verwey and Overbeek, 1948).

\section{Materials and methods}

\subsection{Soil colloid suspension}

The soil sample was collected from broad-leaved forest land in the Olympic Forest Park, Beijing, China. The sample was dried at room temperature $\left(20 \pm 5{ }^{\circ} \mathrm{C}\right)$, ground and sieved through a $0.074 \mathrm{~mm}$ nylon sieve to remove large particles. Soil colloid suspensions were prepared by adding $2.5 \mathrm{~g}$ of soil sample to $500 \mathrm{~mL}$ of Milli-Q water, homogenized by stirring, and sonicated for $60 \mathrm{~min}$. After the solution settled for $24 \mathrm{~h}$, the suspension was recovered by siphoning and further filtered through $1.2 \mu \mathrm{m}$ membrane filter to remove the large suspended matter. Concentrations of soil colloid suspensions were determined by measuring the extinction at $420 \mathrm{~nm}$ with a spectrophotometer (UV5100B, METASH), based on the linear calibration curves between absorbencies and standards (Roy and Dzombak, 1997; Saiers and Hornberger, 1996; Shani et al.,
2008). Analytical methods for soil colloidal chemistry can be found in the Supplementary Material (S1).

The particle size distribution and zeta potential of the soil colloids were measured using a dynamic light scattering analyzer (Zetasizer Nano ZS, Malvern Instruments). The soil colloids were captured on $0.1 \mu \mathrm{m}$ membrane filter by underpressure filtration to make the soil colloids flat. The contact angles $(\theta)$ of diiodomethane with known surface tension parameters on the soil colloids flat were measured using a drop shape analyzer (DSA 100, Kruss). Concentrations of dissolved cations $\left(\mathrm{K}^{+}, \mathrm{Na}^{+}, \mathrm{Ca}^{2+}, \mathrm{Mg}^{2+}\right.$, and $\left.\mathrm{Al}^{3+}\right)$ and anions $\left(\mathrm{Cl}^{-}, \mathrm{F}^{-}, \mathrm{NO}_{3}^{-}\right.$, and $\left.\mathrm{SO}_{4}^{2-}\right)$ in the filtrates of soil colloid suspensions were measured by inductively coupled plasma optical emission spectrometry (Optima 5300DV, Perkin-Elmer) and ion chromatography (ICS-900, Dionex Thermo Fisher), respectively. The morphological analysis of the soil colloid was achieved using scanning electron microscopy (SEM) using a Zeiss SUPRA $55 \mathrm{mi}-$ croscope (at $5 \mathrm{kV}$ ) and energy dispersive spectroscopy (EDS) (Zeiss SUPRA 55 SAPPHIRE, model) (Supplementary Material S1).

The particle size distribution of soil colloids used in this study at $\mathrm{pH}$ between 5.0 and 9.8 was $91.3-825.0 \mathrm{~nm}$, with the fraction $<100 \mathrm{~nm}$ less than $0.4 \%$. In neutral and alkaline conditions, the size distribution and concentration of soil colloids were stable within $24 \mathrm{~h}$ (Supplementary Material S2).

Batch experiments were carried out to study $\mathrm{As}(\mathrm{V})$ adsorption onto soil colloids at different $\mathrm{pH}$ by reacting $25 \mathrm{~mL}$ of $\mathrm{As}(\mathrm{V})$ solutions $\left(0.2-5 \mathrm{mg} \mathrm{L}^{-1} \mathrm{As}\right)$ in $50 \mathrm{~mL}$ polypropylene shaking flasks with $250 \mathrm{mg} \mathrm{L}^{-1}$ of soil colloid suspensions. Stock solution $\left(500 \mathrm{mg} \mathrm{L}^{-1}\right.$ $\mathrm{As}(\mathrm{V})$ ) was prepared from $\mathrm{Na}_{2} \mathrm{HAsO}_{4} \cdot 7 \mathrm{H}_{2} \mathrm{O}$ (Sigma-Aldrich), in Milli-Q water. The initial $\mathrm{pH}$ was adjusted to 5.0, 7.0, and 9.0 using $0.1 \mathrm{M} \mathrm{HCl}$ and $0.1 \mathrm{M} \mathrm{NaOH}$. The flasks were placed in a shaking incubator that was held at $25^{\circ} \mathrm{C}$ and shaken at $180 \mathrm{rpm}$ for $24 \mathrm{~h}$. The mixture was then centrifuged at $2000 \mathrm{~g}$-force for $10 \mathrm{~min}$, filtered through a $0.1 \mu \mathrm{m}$ membrane filter, acidified with $1 \mathrm{M} \mathrm{HNO}_{3}$ to $\mathrm{pH}<2.0$, and analyzed for As concentration within $24 \mathrm{~h}$. The isotherm experiments were performed in triplicate. The data were used to evaluate adsorption isotherms according to Langmuir and the Freundlich isotherms (Supplementary Material S3).

\subsection{Column experiments on co-transport of $A s(V)$ and soil colloid}

Column experiments were conducted with glass chromatographic columns with a length of $20 \mathrm{~cm}$ and an inner diameter of $2.6 \mathrm{~cm}$. The natural aquifer sand was used to simulate the groundwater environment. The sand was collected from an aquifer at a depth of $30 \mathrm{~m}$ below the land surface (the water table was approximately $25 \mathrm{~m}$ below the land surface) at the Astronomy and Earth Sciences Park of the Chinese Academy of Sciences, Chaoyang District, Beijing, China $\left(40.00^{\circ} \mathrm{N}, 116.38^{\circ} \mathrm{E}\right)$, located in the middle of the Yongding River alluvial fan (Ma et al., 2015a). The column was wet-packed in Milli-Q water with a fixed amount of sand with grain sizes between 21 and $212 \mu \mathrm{m}$ (with an average of $70 \mu \mathrm{m}$ ). A $38 \mu \mathrm{m}$ fabric screen and $2 \mathrm{~cm}$ glass bead were placed at each end of the columns. The porosity and bulk density of the packed sand were $0.39 \mathrm{~cm}^{3} \mathrm{~cm}^{-3}$ and $1.59 \mathrm{~g} \mathrm{~cm}^{-3}$, respectively. After packing, the columns were pre-conditioned with around 50 pore volumes (PVs) of $0.001 \mathrm{~mol} \mathrm{~L}^{-1} \mathrm{HCl}$ solution ( $\mathrm{pH} \sim 3$ ) using a peristaltic pump (BT$1001 \mathrm{~F}$, Longer) in the up-flow mode.

In neutral and alkaline conditions ( $\mathrm{pH} 7.2,8.6$, and 9.8), 25 PVs $(\sim 15 \mathrm{~h})$ of $200 \mu \mathrm{g} \mathrm{L}^{-1} \mathrm{As}(\mathrm{V})$ solutions with different concentrations of soil colloids suspensions $\left(0,25,100\right.$, and $\left.150 \mathrm{mg} \mathrm{L}^{-1}\right)$ were injected into the columns, followed by elution with 25 PVs of Milli$\mathrm{Q}$ water with the same $\mathrm{pH}$ as the $\mathrm{As}(\mathrm{V})$ solution. At $\mathrm{pH}$ 5.0, 40 PVs $(\sim 24 \mathrm{~h})$ of $\mathrm{As}(\mathrm{V})$ solution and $40 \mathrm{PVs}$ of Milli-Q water were used for $\mathrm{As}(\mathrm{V})$ adsorption and elution, respectively. At $\mathrm{pH} 9.8, \mathrm{As}(\mathrm{V})$ solution mixed with filtrated soil colloid suspension with $0.1 \mu \mathrm{m}$ membrane 
was used as influent to exclude effects of soil colloid in a control experiment. To avoid $\mathrm{As}(\mathrm{V})$ adsorption on soil colloids outside the columns, a union tee was installed to mix them close to the inlet. All column experiments were at a constant Darcy velocity of $0.151 \mathrm{~cm} \mathrm{~min}^{-1}$.

Concentrations of dissolved $\mathrm{As}(\mathrm{V})\left(\mathrm{C}_{\mathrm{d}-\mathrm{As}}\right)$, total $\mathrm{As}(\mathrm{V})\left(\mathrm{C}_{\mathrm{As}}\right)$, soil colloid $\left(C_{\text {colloid }}\right)$ and $\mathrm{pH}$ in effluent were measured for each $1-5 \mathrm{PVs}$. An aliquot was filtered through a $0.1 \mu \mathrm{m}$ membrane filter to determine $C_{d-A s}$, while an aliquot $(4 \mathrm{ml})$ without filtration was mixed in $1 \mathrm{ml} 0.5 \mathrm{M} \mathrm{H}_{3} \mathrm{PO}_{4}$ solution to determine $\mathrm{C}_{\mathrm{As}}$. Arsenic concentrations were analyzed by atomic fluorescence spectrometry (AFS-9800, KCHG). Concentrations of soil colloids ( $\left.\mathrm{C}_{\text {colloid }}\right)$ in the effluent were measured by spectrophotometer as mentioned above. The solution $\mathrm{pH}$ was monitored by a $\mathrm{pH} / \mathrm{ORP}$ meter ( $\mathrm{S} 400$ SevenExcellence, METTLER TOLEDO). Concentrations of dissolved cations $\left(\mathrm{K}^{+}, \mathrm{Na}^{+}, \mathrm{Ca}^{2+}, \mathrm{Mg}^{2+}\right.$, and $\left.\mathrm{Al}^{3+}\right)$ and anions $\left(\mathrm{Cl}^{-}, \mathrm{F}^{-}, \mathrm{NO}_{3}^{-}\right.$, and $\mathrm{SO}_{4}^{2-}$ ) were measured to calculate ionic strength. Arsenic species in the effluent were determined by high performance liquid chromatography hydride generation atomic fluorescence spectrophotometer (PSA-10.825, PS Analytical). The speciation results showed that $\operatorname{As}(\mathrm{V})$ was not reduced during the experiments (the data was not shown).

Conservative tracer $\left(\mathrm{Br}^{-}\right)$was used to check hydraulic characteristics of the columns. During column experiments, $\mathrm{Br}^{-}$solution ( $500 \mu \mathrm{g} \mathrm{L}^{-1}$ ) was introduced into the column as the same manner as the co-transport experiments. Effluent $\mathrm{Br}^{-}$concentration was determined using an ion chromatography (ICS-900, Dionex Thermo Fisher). All column experiments were conducted in duplicate.

\subsection{Mathematical models}

Arsenic(V) adsorption onto soil colloids is ignored due to low adsorption (Supplementary Material S3). A chemical nonequilibrium model was used to simulate the $\mathrm{As}(\mathrm{V})$ transport and retention in the columns. Kinetic adsorption sites, including instantaneous equilibrium adsorption sites (Site- $1_{\mathrm{As}}$, the sites are always at equilibrium) and first-order kinetic adsorption sites (Site2 As), were considered (Cameron and Klute, 1977; Selim et al., 1976). $S_{1}$ and $S_{2}$ are the adsorbed $A s(V)$ contents in sand of Site- $1_{A s}$ and Site- $2_{\mathrm{As}}$, respectively. In Site- $1_{\mathrm{As}}$, the fraction of instantaneous adsorption sites $(F)$ and linear adsorption coefficient $\left(K_{d}\right)$ are used to account for $\mathrm{As}(\mathrm{V})$ instantaneous adsorption on the sand surfaces. In Site- $2_{\mathrm{As}}$, the first-order rate coefficient for non-equilibrium adsorption $(\alpha)$ and the first-order decay coefficients for degradation in the solid phase $\left(\mu_{\mathrm{s}}\right)$ are taken into account to calculate the time-dependent adsorption. The solute transport model is outlined in details in the Supplementary Material (S4).

Transport and retention of soil colloids in the columns were simulated using a one-dimensional model of the particle transport using attachment/detachment, chemical nonequilibrium with twosite kinetic retention (Bradford et al., 2003). The first kinetic Site-

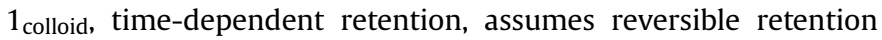
using first-order retention $\left(\mathrm{k}_{1 \mathrm{a}}\right)$ and detachment $\left(\mathrm{k}_{1 \mathrm{~d}}\right)$ coefficients, and a Langmuirian approach blocking function (Adamczyk et al., 1994; Wang et al., 2012) to account for maximum soil colloid content on Site- $1_{\text {colloid }}$ of sand $\left(S_{\max 1}\right)$. The second kinetic Site2 colloid, depth-dependent retention, assumes irreversible retention using a first-order retention coefficient $\left(\mathrm{k}_{2 \mathrm{a}}\right)$ and a depthdependent blocking function (Bradford et al., 2003; Wang et al., 2012). $s_{1}$ and $s_{2}$ are the retained colloid contents in column sand associated with Site- $1_{\text {colloid }}$ and Site- $2_{\text {colloid, }}$ respectively. Details on the colloid transport model and operative equations are shown in Supplementary Material (S5).

The interactions between soil colloids and the sand surfaces were elucidated on the basis of the Derjaguin-Landau-Verwey-
Overbeek (DLVO) theory (Derjaguin and Landau, 1941; Verwey and Overbeek, 1948), which is the basis for understanding colloid transport and has a considerable amount of experimental support (Shani et al., 2008; Shen et al., 2015). A series of data (e.g., zeta potential, the radius, ionic strength, and contact angle) were used to calculate DLVO theory to elucidate the mechanisms of soil colloid transport. Details on DLVO theory and operative equations are given in the Supplementary Material (S6).

\section{Results and discussion}

\subsection{Effect of $\mathrm{pH}$ on soil colloid-As(V) co-transport}

BTCs for As(V) in Milli-Q water and As(V) with soil colloids in the saturated sand columns at different $\mathrm{pH}$ are shown in Fig. 1. In this study, $\mathrm{As}(\mathrm{V})$ transport increased with increasing $\mathrm{pH}$ from 5.0 to 7.2 (Fig. 1a and b), showing that high $\mathrm{pH}$ was conducive to $\mathrm{As}(\mathrm{V})$ transport in porous media (Charlet et al., 2011; Guo et al., 2014). Different $\mathrm{pH}$ levels near the column inlet were close to influent $\mathrm{pH}$ levels. This caused different $\mathrm{As}(\mathrm{V})$ transport, although $\mathrm{pH}$ levels in the effluents were slightly different (Supplementary Material S7). An inconspicuous increase in $\mathrm{As}(\mathrm{V})$ transport was observed when pH increased from 7.2 to 9.8 (Fig. 1 b, c, and d). This can be explained by the little difference in $\mathrm{As}(\mathrm{V})$ adsorption on sand at these $\mathrm{pH}$ levels (between 7.2 and 9.8) (Ma et al., 2015a). The breakthrough plateaus of $\mathrm{As}(\mathrm{V})$ (Fig. 1a, b, and $\mathrm{c}$ ) and $\mathrm{As}(\mathrm{V})$ recovery in the effluent (Table 1) with the presence of soil colloids were roughly identical to those in Milli-Q water at $\mathrm{pH}$ between 5.0 and 8.6, showing that the effect of soil colloids on $\mathrm{As}(\mathrm{V})$ transport was not obvious at these $\mathrm{pH}$ levels (between 5.0 and 8.6). In addition, $\mathrm{As}(\mathrm{V})$ concentration in the effluent greatly increased immediately after the influent was switched from As(V)-soil colloid solution to Milli$\mathrm{Q}$ water at $42.5 \mathrm{PVs}$ for $\mathrm{pH} 5.0$ (Fig. 1a) and at $26 \mathrm{PVs}$ for $\mathrm{pH} 7.2$ and 8.6 (Fig. $1 \mathrm{~b}$ and c), which results from an abrupt increase in the effluent $\mathrm{pH}$ due to lack of buffer ability of Milli-Q water relative to soil colloid suspensions (Supplementary Material S7) (Ma et al., 2015a).

However, soil colloids obviously increased $\mathrm{As}(\mathrm{V})$ transport at $\mathrm{pH}$ 9.8 (Fig. 1d). Arsenic(V) recovery in the effluent increased in the presence of soil colloids at the time of influent shift (from $52.9 \%$ to 66.8\%) (Table 1). In the first 10 PVs, soil colloid-promoted $\mathrm{As}(\mathrm{V})$ transport $\left(\mathrm{C}_{\mathrm{As}} / \mathrm{C}_{\mathrm{As} 0}\right)$ and $\mathrm{As}(\mathrm{V})$ recovery in the effluent increased by more than 0.5 (50\% $\mathrm{As}(\mathrm{V})$ co-transport with soil colloids) and $20 \%$ (from $20.7 \%$ to $42.4 \%$ ) (Table 1 ), respectively, relative to $\mathrm{As}(\mathrm{V})$ transport in Milli-Q water. The evident colloid-promoted transport was unlikely due to the weak $\mathrm{As}(\mathrm{V})$ adsorption $(<3.7 \%)$ onto soil colloids (Supplementary Material S3), which was also supported by the fact that dissolved As concentration $\left(C_{d-A s}\right)$ was identical to total As $\left(C_{A s}\right)$ in the effluents (Supplementary Material S8). In the control experiment, $\operatorname{As}(\mathrm{V})$ transport in filtrate of soil colloid suspension was identical to that in Milli-Q water at pH 9.8. Therefore molecules and dissolved ions contributed little to promoting $\mathrm{As}(\mathrm{V})$ transport (Supplementary Material S9).

\subsection{Effect of soil colloid concentration on $A s(V)$ transport}

Forward breakthrough of $\mathrm{As}(\mathrm{V})$ was followed by slope side of plateau region with soil colloid concentrations of $25-150 \mathrm{mg} \mathrm{L}^{-1}$. showing rapid transport relative to $\mathrm{As}(\mathrm{V})$ transport in the absence of soil colloids (Fig. 2a). The height of those plateaus was independent of soil colloid concentrations, which was different from other observations, showing the increase in plateau height of facilitated hydroxyatrazine transport with increasing concentration of clay colloid (Wang et al., 2014). However, the As(V) breakthrough time decreased with the increase in concentrations of soil colloids. 

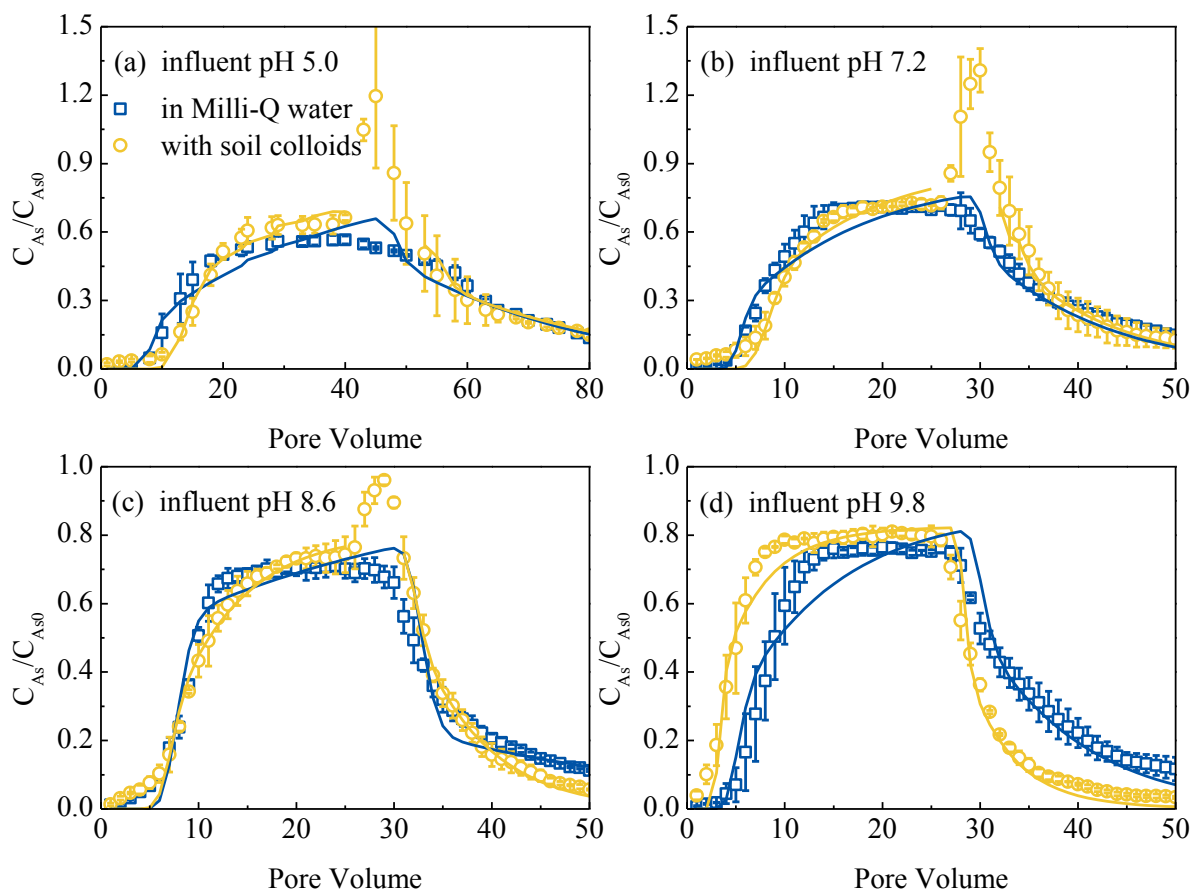

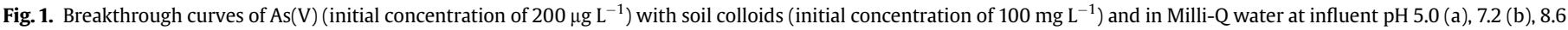
(c), and 9.8 (d). Symbols show observed data and solid lines show simulation fitting. Error bars represent the standard deviation of two replicates.

Table 1

Fitted parameters of $\mathrm{As}(\mathrm{V})$ transport in columns to the two-site sorption model (chemical nonequilibrium).

\begin{tabular}{|c|c|c|c|c|c|c|c|c|}
\hline Influent & $\begin{array}{l}\text { As }(\mathrm{V}) \text { recovery-1 }{ }^{\mathrm{a}} \\
(\%)\end{array}$ & $\begin{array}{l}\mathrm{As}(\mathrm{V}) \text { recovery- } 2^{\mathrm{b}} \\
(\%)\end{array}$ & $\mathrm{F}^{\mathrm{c}}$ & $\begin{array}{l}\mathrm{K}_{\mathrm{d}}^{\mathrm{d}} \\
\left(\mathrm{cm}^{3} \cdot \mathrm{g}^{-1}\right)\end{array}$ & $\mathrm{R}^{\mathrm{e}}$ & $\begin{array}{l}\mu_{\mathrm{s}}^{\mathrm{f}} \times 10^{4} \\
\left(\mathrm{~min}^{-1} \times 10^{4}\right)\end{array}$ & $\begin{array}{l}\alpha^{g} \times 10^{3} \\
\left(\min ^{-1} \times 10^{3}\right)\end{array}$ & $\mathrm{r}^{2 \mathrm{~h}}$ \\
\hline pH 5 in Milli-Q water & $6.1 \pm 0.8$ & $39.4 \pm 2.0$ & $1.8 \mathrm{E}-01 \pm 1.0 \mathrm{E}-02$ & $1.8 \pm 0.05$ & $2.4 \pm 0.12$ & $1.9 \pm 0.46$ & $1.5 \pm 0.36$ & 0.93 \\
\hline $\begin{array}{l}\text { pH } 5 \text { with } 100 \mathrm{mgL}^{-1} \text { soil } \\
\text { colloids }\end{array}$ & $4.1 \pm 0.6$ & $40.1 \pm 1.0$ & $3.6 \mathrm{E}-01 \pm 1.3 \mathrm{E}-01$ & $2.0 \pm 0.6$ & $4.0 \pm 0.17$ & $0.47 \pm 0.35$ & $1.2 \pm 0.72$ & 0.98 \\
\hline pH 7.2 in Milli-Q water & $18.6 \pm 1.4$ & $48.3 \pm 1.6$ & $1.9 \mathrm{E}-01 \pm 2.1 \mathrm{E}-03$ & $0.75 \pm 0.04$ & $1.7 \pm 0.04$ & $2.5 \pm 2.2$ & $2.7 \pm 0.50$ & 0.95 \\
\hline $\begin{array}{l}\text { pH } 7.2 \text { with } 100 \mathrm{mgL}^{-1} \text { soil } \\
\text { colloids }\end{array}$ & $14.3 \pm 1.8$ & $45.7 \pm 1.3$ & $4.3 \mathrm{E}-01 \pm 7.4 \mathrm{E}-03$ & $0.72 \pm 0.15$ & $2.4 \pm 0.27$ & $2.3 \pm 2.5$ & $3.3 \pm 1.3$ & 0.98 \\
\hline pH 8.6 in Milli-Q water & $15.6 \pm 0.4$ & $47.6 \pm 0.9$ & $2.6 \mathrm{E}-01 \pm 8.5 \mathrm{E}-04$ & $0.90 \pm 0.25$ & $2.0 \pm 0.30$ & $2.8 \pm 2.6$ & $1.9 \pm 1.2$ & 0.96 \\
\hline $\begin{array}{l}\text { pH } 8.6 \text { with } 100 \mathrm{mgL}^{-1} \text { soil } \\
\text { colloids }\end{array}$ & $15.0 \pm 1.2$ & $46.6 \pm 1.9$ & $4.3 \mathrm{E}-01 \pm 1.1 \mathrm{E}-02$ & $0.56 \pm 0.01$ & $2.1 \pm 0.00$ & $6.1 \pm 2.4$ & $5.0 \pm 0.74$ & 0.99 \\
\hline pH 9.8 in Milli-Q water & $20.7 \pm 4.8$ & $52.9 \pm 2.7$ & $2.1 \mathrm{E}-01 \pm 4.6 \mathrm{E}-02$ & $0.57 \pm 0.11$ & $1.5 \pm 0.22$ & $4.0 \pm 0.98$ & $3.4 \pm 0.36$ & 0.94 \\
\hline $\begin{array}{l}\text { pH } 9.8 \text { with } 25 \mathrm{mgL}^{-1} \text { soil } \\
\text { colloids }\end{array}$ & $42.5 \pm 5.9$ & $63.3 \pm 0.8$ & $1.8 \mathrm{E}-06 \pm 1.1 \mathrm{E}-06$ & $0.27 \pm 0.05$ & $1.0 \pm 0.00$ & $13 \pm 2.9$ & $7.0 \pm 1.9$ & 0.97 \\
\hline $\begin{array}{l}\text { pH } 9.8 \text { with } 100 \mathrm{mgL}^{-1} \text { soil } \\
\text { colloids }\end{array}$ & $47.7 \pm 2.9$ & $66.8 \pm 1.9$ & $8.0 \mathrm{E}-07 \pm 5.8 \mathrm{E}-07$ & $0.23 \pm 0.04$ & $1.0 \pm 0.00$ & $15 \pm 6.6$ & $6.1 \pm 3.2$ & 0.98 \\
\hline $\begin{array}{l}\text { pH } 9.8 \text { with } 150 \mathrm{mgL}^{-1} \text { soil } \\
\text { colloids }\end{array}$ & $52.9 \pm 0.1$ & $69.4 \pm 0.3$ & $6.7 \mathrm{E}-06 \pm 7.3 \mathrm{E}-06$ & $0.24 \pm 0.09$ & $1.0 \pm 0.00$ & $15 \pm 6.0$ & $4.4 \pm 3.0$ & 0.98 \\
\hline
\end{tabular}

${ }^{a} \mathrm{As}(\mathrm{V})$ recovery in the effluent at $10 \mathrm{PV}$.

b $\mathrm{As}(\mathrm{V})$ recovery in the effluent when the influent was switched from $\mathrm{As}(\mathrm{V})$ (-soil colloid) solutions to Milli- $\mathrm{Q}$ water.

c The fraction of instantaneous adsorption sites was expressed in scientific notation due to large difference of orders of magnitude.

d Linear adsorption coefficient.

e The retardation factor was calculated as $\mathrm{R}=1+\mathrm{F} \mathrm{K}_{\mathrm{d}} \rho / \theta$.

${ }^{f}$ The first-order decay coefficients for degradation in the solid phase.

$\mathrm{g}$ The first-order rate coefficient for non-equilibrium adsorption.

h Squared Person's correlation coefficient.

This indicates that colloid-promoted transport of $\mathrm{As}(\mathrm{V})$ is more evident with high soil colloid concentrations than with low concentrations. In comparison with low concentrations (25 and $\left.100 \mathrm{mg} \mathrm{L}^{-1}\right)$, soil colloid at concentration of $150 \mathrm{mg} \mathrm{L}^{-1}$ increased $\mathrm{As}(\mathrm{V})$ transport $\left(\mathrm{C}_{\mathrm{As}} / \mathrm{C}_{\mathrm{As} 0}\right)$ by more than 0.2 and $\mathrm{As}(\mathrm{V})$ recovery in the effluent at 10 PV by 5-10\%. Adsorption on soil colloids was not enough to account for this promoted transport due to the limited adsorption of $\mathrm{As}(\mathrm{V})$ on the soil colloids (Supplementary Material S3). Our observed results were consistent with a study by Saiers and Hornberger (1996), who reported that kaolinite colloid facilitated ${ }^{137} \mathrm{Cs}$ transport through saturated sand columns with low ${ }^{137}$ Cs adsorption.

\subsection{Simulation of $A s(V)$ transport}

Saiers and Hornberger (1996) suggested that the three-phase model better reproduces the experimental data of kaolinite colloid-facilitated transport of ${ }^{137} \mathrm{Cs}$ than the two-phase model. 

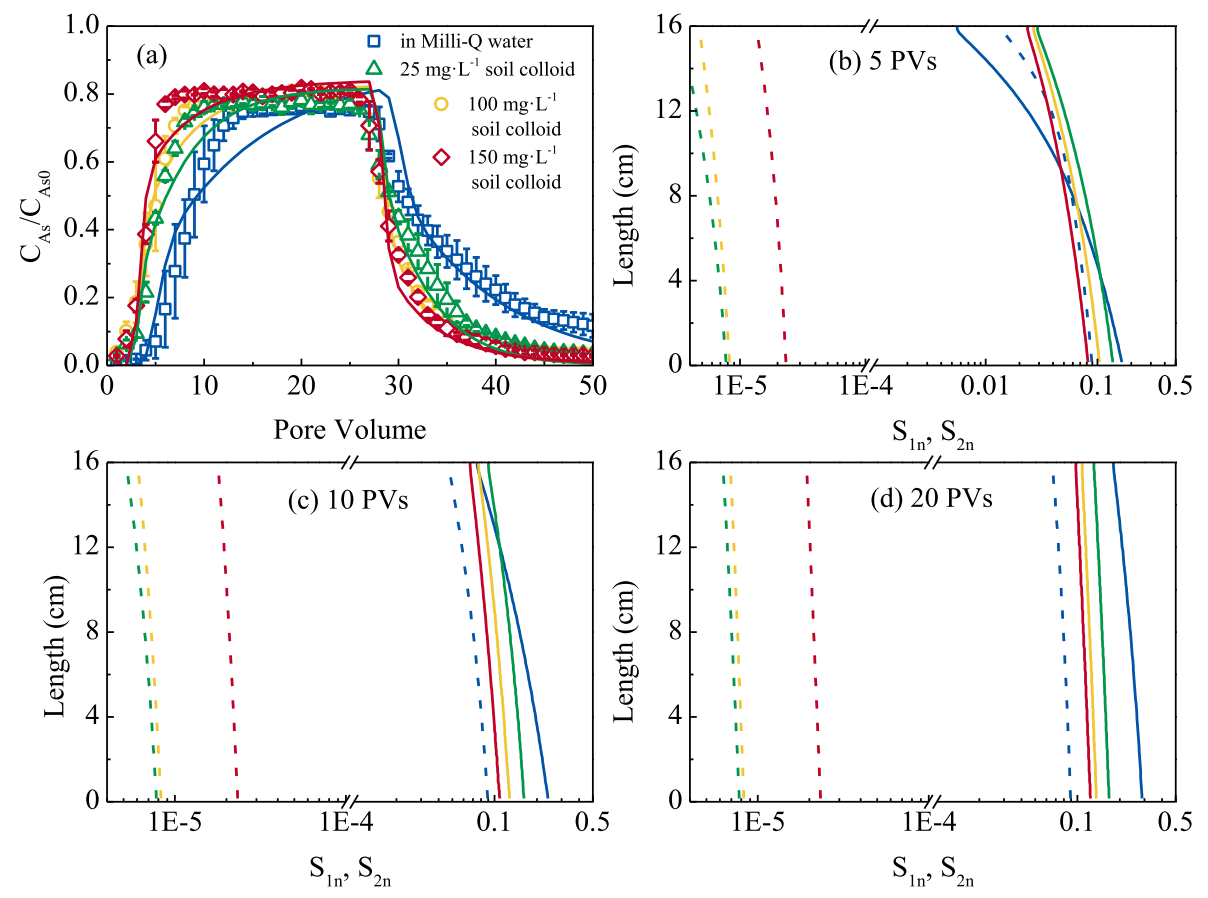

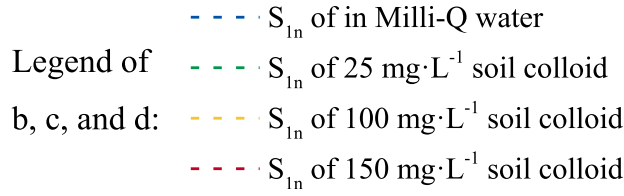

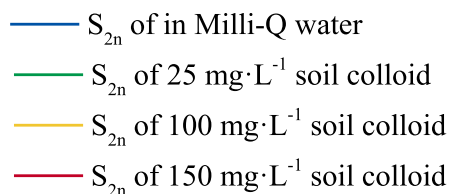

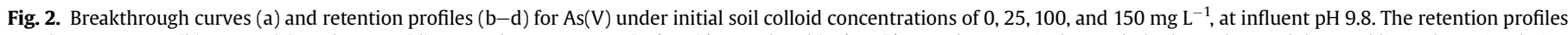

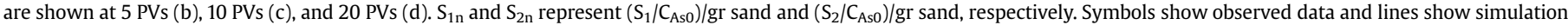
fitting. Error bars represent the standard deviation of two replicates.

However, there were clear inaccuracies of the model considering the colloid as a carrier. In this study, although $\mathrm{As}(\mathrm{V})$ adsorption on soil colloids were higher around 4-10 times than on sand (Ma et al., 2015a) and adsorbed-As(V) concentrations on soil colloids were higher than As concentrations of some As-contaminated soils (Ma et al., 2016), the adsorption was much less than on ferrous minerals (e.g., ferrihydrite, siderite, goethite, magnetite, and mixture of siderite and goethite) (Asta et al., 2009; Guo et al., 2010; Jessen et al., 2005; Liang and Zhao, 2014). Soil colloid suspensions with concentrations of $250 \mathrm{mg} \mathrm{L}^{-1}$ only adsorbed $8.9 \%, 5.7 \%$, and $3.7 \%$

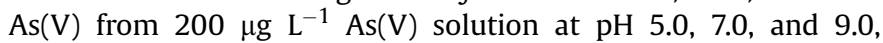
respectively (Supplementary Material S3). Lower adsorption on soil colloids was expected to occur in porous sand column experiments with 25-150 $\mathrm{mg} \mathrm{L}^{-1}$ soil colloids, and $200 \mu \mathrm{g} \mathrm{L}^{-1} \mathrm{As}(\mathrm{V})$. Therefore, $\mathrm{As}(\mathrm{V})$ adsorption onto soil colloids was low and can be ignored.

Based on a two-phase chemical non-equilibrium model, the inverse routine was directly implemented in HYDRUS-1D 4.xx and used to estimate transport and reaction parameters using a Levenberg-Marquardt algorithm (Marquardt, 1963). The fitted curves are shown in Figs. 1 and 2, and Table 1 presents the fitted parameters of those observations. Prior to fitting the simulation, the breakthrough curves of conservative tracer $\left(\mathrm{Br}^{-}\right)$were used to estimate the longitudinal dispersivity, $\lambda$, using the CXTFIT code (STANMOD) (Supplementary Material S10) (Toride et al., 1999).

Abrupt increases in $\mathrm{As}(\mathrm{V})$ in Fig. $1 \mathrm{a}, \mathrm{b}$, and $\mathrm{c}$ at the time of influent shift were ignored during the simulation. The correlation coefficient $\left(r^{2}>0.93\right)$ between the experimental and predicted data confirmed satisfactory fits (Figs. 1 and 2). The linear adsorption coefficient, $\mathrm{K}_{\mathrm{d}}$, decreased with the increase in $\mathrm{pH}$, showing the decrease in $\mathrm{As}(\mathrm{V})$ adsorption with increasing $\mathrm{pH}$. The first-order rate coefficient for non-equilibrium adsorption, $\alpha$, and the firstorder decay coefficients for degradation in the solid phase, $\mu_{\mathrm{s}}$, varied from $1.2 \times 10^{-3} \mathrm{~min}^{-1}$ to $7.0 \times 10^{-3} \mathrm{~min}^{-1}$ and from $0.47 \times 10^{-4} \mathrm{~min}^{-1}$ to $15 \times 10^{-4} \mathrm{~min}^{-1}$ respectively (Table 1 ). Although the values of $\alpha$ and $\mu_{\mathrm{s}}$ changed with experiment conditions, both were relatively low, indicating that $\mathrm{As}(\mathrm{V})$ adsorption onto Site- 2 As and degradation from Site- 2 As were slow and thus had limited effect on $\mathrm{As}(\mathrm{V})$ transport, especially at the initial stage.

Noticeably, the fraction of instantaneous adsorption sites, F, in the presence of soil colloids at $\mathrm{pH} 9.8$ was much lower than those with or without soil colloids at pH 5.0, 7.2, and 8.6 (roughly 5 orders of magnitude) (Table 1). This indicates that trace amounts of $\mathrm{As}(\mathrm{V})$ would be instantaneously adsorbed onto Site- $1_{\text {As }}$ in the presence of soil colloids at $\mathrm{pH} 9.8$, while around $20-40 \% \mathrm{As}(\mathrm{V})$ was adsorbed onto Site- $1_{\mathrm{As}}$ in other experimental conditions. The decreases in $\mathrm{F}$ values were comparable to the report by Jellali et al. (2010) who observed that the increase in the flow rate of ammonium solutions from $15 \mathrm{ml} \mathrm{min}^{-1}$ to $45 \mathrm{ml} \mathrm{min}{ }^{-1}$ led to significant decreases in instantaneous adsorption. The present study was carried out at a constant flow rate, at $\mathrm{pH} 9.8$ and concentrations of soil colloids between 25 and $150 \mathrm{mg} \mathrm{L}^{-1}$. It indicates that soil colloid-promoted $\mathrm{As}(\mathrm{V})$ rapid transport was caused by the decrease in instantaneous adsorption onto Site- $1_{\text {As }}$. Because of very low $F$ values, the retardation factor $(R)$ was calculated as roughly equal to 1 (Table 1 ), showing non-retardant $\mathrm{As}(\mathrm{V})$ transport in the presence of soil colloids at $\mathrm{pH} 9.8$ relative to other experiment conditions.

The retention profiles (RPs) for $\mathrm{As}(\mathrm{V})$ in the porous media were evaluated at different PVs from 5 to 20 at pH 9.8 (Fig. 2b, c, and d). 
The RPs are plotted as initial $\mathrm{As}(\mathrm{V})$ concentration normalized-As(V) retention $\left(\mathrm{As}(\mathrm{V})\right.$ retention in the sand columns, $\mathrm{S}_{1}$ and $\mathrm{S}_{2}$, divided by the initial $\mathrm{As}(\mathrm{V})$ concentration, $\mathrm{C}_{\mathrm{As} 0}$ ) per gram of dry sand as a function of distance from the column inlet. $S_{1 n}$ and $S_{2 n}$ represent $\left(\mathrm{S}_{1} / \mathrm{C}_{\mathrm{As} 0}\right) / \mathrm{gr}$ sand and $\left(\mathrm{S}_{2} / \mathrm{C}_{\mathrm{As}}\right) / \mathrm{gr}$ sand, respectively. Arsenic $(\mathrm{V})$ instantaneous adsorption $\left(\mathrm{S}_{1 \mathrm{n}}\right)$ was roughly equal to 0.1 at profiles with the absence of the soil colloids, which is much higher than that $\left(<10^{-4}\right)$ of $\mathrm{As}(\mathrm{V})$ instantaneous adsorption $\left(\mathrm{S}_{1 \mathrm{n}}\right)$ in profiles for the soil colloid-treated experiments (Fig. 2b, c, and d). In comparison with $\mathrm{S}_{1 \mathrm{n}}$, the first-order kinetic adsorption $\left(\mathrm{S}_{2 \mathrm{n}}\right)$ is higher in the presence of soil colloids, showing the predominant role of Site- $2_{\mathrm{As}}$ in As adsorption. At 5 PVs, more $\mathrm{As}(\mathrm{V})$ adsorption on Site- $2_{\mathrm{As}}\left(\mathrm{S}_{2 \mathrm{n}}\right)$ was observed near the column outlet in the soil colloid-treated experiments than in the soil colloid-free experiments, while higher $\mathrm{As}(\mathrm{V})$ retention was found near the column inlet in the soil colloid-free experiments (Fig. 2b). Accordingly, high As(V) concentrations which were co-transported with soil colloids to column outlet were earlier than $\mathrm{As}(\mathrm{V})$ transport without the colloids. During transport, the increase in $S_{2 n}$ in the column with increasing pore volumes was observed in the soil colloid-free experiments, which is more apparent than the increase in $S_{2 n}$ in column during soil colloid-treated experiments (Fig. 2b, c, and d). At 10 PVs, As(V) adsorption (including $S_{1}$ and $S_{2}$ ) in the soil colloid-free column exceeded that in the soil colloid-treated columns. Therefore, the fast $\mathrm{As}(\mathrm{V})$ transport in the presence of the colloid was caused by low adsorption in the column, including the instantaneous adsorption and the first-order kinetic adsorption.

\subsection{Transport of soil colloids}

BTCs and RPs for soil colloids in the columns were evaluated at different $\mathrm{pH}$ levels between 5.0 and 9.8. Fig. 3 and Table 2 present the simulation results and fitted parameters, respectively. Overall, retention of soil colloid decreased with increasing $\mathrm{pH}$ (Fig. 3). Although the breakthrough plateaus were identical at pH 8.6 and 9.8 (Fig. 3c, d, e, and f), the kinetic model parameters and soil colloid recovery in the effluent (Table 2) were quite different at those two pH levels, showing the difference in soil colloid transport. The two-kinetic site model parameters $\mathrm{k}_{1 \mathrm{a}}, \mathrm{k}_{2 \mathrm{a}}$, and $\mathrm{s}_{\max 1}$ decreased with increasing $\mathrm{pH}$, while $\mathrm{k}_{1 \mathrm{~d}}$ and $\mathrm{k}_{1 \mathrm{~d}} / \mathrm{k}_{1 \mathrm{a}}$ increased (Table 2). In alkaline conditions, especially at $\mathrm{pH} \mathrm{9.8,} \mathrm{the} \mathrm{values} \mathrm{of}$ $\mathrm{k}_{1 \mathrm{~d}} / \mathrm{k}_{1 \mathrm{a}}$ were higher than 1 (Table 2), indicating that retention of soil colloids on time-dependent sites (Site- $1_{\text {colloid }}$ ) was low due to the stronger detachment interaction between soil colloids and sands than attachment (Sun et al., 2015a). In contrast, soil colloids were readily retained on the sand in acidic environments.

The RPs are plotted as initial soil colloid concentrationnormalized soil colloid retention (soil colloid retention in the

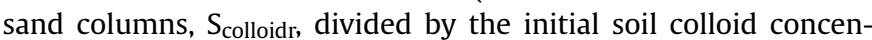
tration $\mathrm{C}_{\text {colloido }}$ ) per gram of dry sand as a function of distance from the column inlet. Due to the difficulty in distinguishing soil colloid from sand chipping, soil colloid retention in the sand columns was not measured in this study. However, the values of model fitting was employed to describe soil colloid retention in all columns (Sun et al., 2015b; Wang et al., 2012; Wang et al., 2013). The amount of retained soil colloids sharply decreased with increasing $\mathrm{pH}$. The strained soil colloid was mostly retained near the column inlet. The normalized soil colloid retention decreased with increasing distance from the column inlet (Fig. $3 \mathrm{~g}$ ). The small pores caused soil colloids to be blocked near the column inlet, which resulted in dead-ends of collector pores and consequently restricted mobility of soil colloids in continuous pore networks (Bradford and Bettahar 2006; Liang et al., 2013).

At $\mathrm{pH}$ 9.8, regardless of concentrations of soil colloids $(25,100$, and $150 \mathrm{mg} \mathrm{L}^{-1}$ ), the breakthrough plateaus were similar (Fig. 3d, e, and f). However, the soil colloid retention decreased with decreasing concentrations of soil colloids (Fig. 3g). Accordingly, $\mathrm{k}_{2 \mathrm{a}}$, the first-order retention coefficient on Site- $2_{\text {colloid, }}$ showed the same trend (Table 2).

DLVO theory was used to calculate the interaction forces between the soil colloid and the sand, assuming plate-plate interactions (Feriancikova and Xu, 2012; Wu et al., 2013), in order to explain the mechanisms of soil colloid transport and retention in porous media. The DLVO energy interactions, the sum of van der Waals attraction and electric double layer repulsion between the soil colloid and the sand surface, were calculated. Results are shown in Fig. 4, and parameters used in calculation are listed in the Supplementary Material (S11). Under the $\mathrm{pH}$ of the experiments, the corresponding zeta potentials of the soil colloids $(-15.7$ to $-21.6 \mathrm{mV}$ ) and sand ( -23.1 to $-40.8 \mathrm{mV}$ ) increased with decreasing $\mathrm{pH}$ (Supplementary Material S11), which could be explained by the compression of the electric double layer as a result of high $\mathrm{H}^{+}$concentration (Ma et al., 2015b). However, the radius of the soil colloids (119.8-168.2 nm) increased with decreasing $\mathrm{pH}$ due to coagulation in acidic conditions.

Since the major ions (i.e., $\mathrm{K}^{+}, \mathrm{Na}^{+}, \mathrm{Ca}^{2+}, \mathrm{Mg}^{2+}, \mathrm{Al}^{3+}, \mathrm{Cl}^{-}, \mathrm{F}^{-}, \mathrm{NO}_{3}^{-}$ and $\mathrm{SO}_{4}^{2-}$ ) were dissolved at different $\mathrm{pH}$, colloidal suspensions had the specific ionic strength $(\sim 4.5-\sim 7 \mathrm{mM})$ in column experiments (Table S11). Calculations showed that the magnitude of the primary energy barrier ranged from $\sim 100$ to $\sim 300 \mathrm{kT}$ (Fig. 4a), which increased with increasing $\mathrm{pH}$ and decreasing ionic strength with the opposite variation trend to $\mathrm{k}_{1 \mathrm{a}}$, indicating that soil colloid transport readily increased with increasing $\mathrm{pH}$ and with decreasing ionic strength. At pH 5.0-8.6, soil colloid-sand interaction energy readily exceeded the primary energy barrier $(\sim 100-\sim 150 \mathrm{kT})$ and thus soil colloids irreversibly deposited into the primary energy minimum. But, at pH 9.8, soil colloid was difficult to deposit into the primary energy minimum due to the high primary energy barrier $(>250 \mathrm{kT}$ ). The retention of the soil colloids at $\mathrm{pH} 9.8$ possibly occurred mainly through their entrapment within the secondary energy minimum (Feriancikova et al., 2013; Wang et al., 2011b), where the soil colloid is easily removed by kinetic energy of diffusing (Fig. 4b). Because of low ionic strength, the sand-colloid system with soil colloid of $25 \mathrm{mg} \mathrm{L}^{-1}$ at $\mathrm{pH} 9.8$ had a higher primary energy barrier and a shallower secondary energy minimum than those with soil colloid concentrations of $100 \mathrm{mg} \mathrm{L}^{-1}$ and $150 \mathrm{mg} \mathrm{L}^{-1}$ at $\mathrm{pH} 9.8$. This indicated that the soil colloid with low concentrations at $\mathrm{pH} 9.8$ was more readily transported in comparison with those with high concentrations. The trend extended the results of the soil colloid transport model.

\subsection{Mechanism and hypothesis of soil colloid-promoted As(V) transport}

Soil colloid-promoted $\mathrm{As}(\mathrm{V})$ transport was observed in porous media with low $\mathrm{As}(\mathrm{V})$ adsorption onto soil colloid. Less retained cotransport of $\mathrm{As}(\mathrm{V})$ and soil colloid occurred at $\mathrm{pH} 9.8$, although it was retarded under other $\mathrm{pH}$ conditions, suggesting that a repulsion between sand and soil colloid was the basis of the phenomenon. The rapid transport of kaolinite colloids was reported in kaolinite colloid-facilitated ${ }^{137} \mathrm{Cs}$ transport (Saiers and Hornberger, 1996), which verified our viewpoint. Although As(V) transport at $\mathrm{pH} 8.6$ was identical to that at pH 9.8 in the absence of soil colloids (Fig. 1c and d), the colloid-promoted transport was not observed in the presence of soil colloids at $\mathrm{pH}$ 8.6. However, evident colloidpromoted $\mathrm{As}(\mathrm{V})$ transport was found at $\mathrm{pH} 9.8$, indicating that strong repulsion between sand and soil colloids could lead to soil colloid-promoted $\mathrm{As}(\mathrm{V})$ transport. During kaolinite colloidfacilitated ${ }^{137} \mathrm{Cs}$ transport, high ionic strength decreased repulsion for kaolinite colloids, and thus the level of facilitated ${ }^{137} \mathrm{Cs}$ transport 

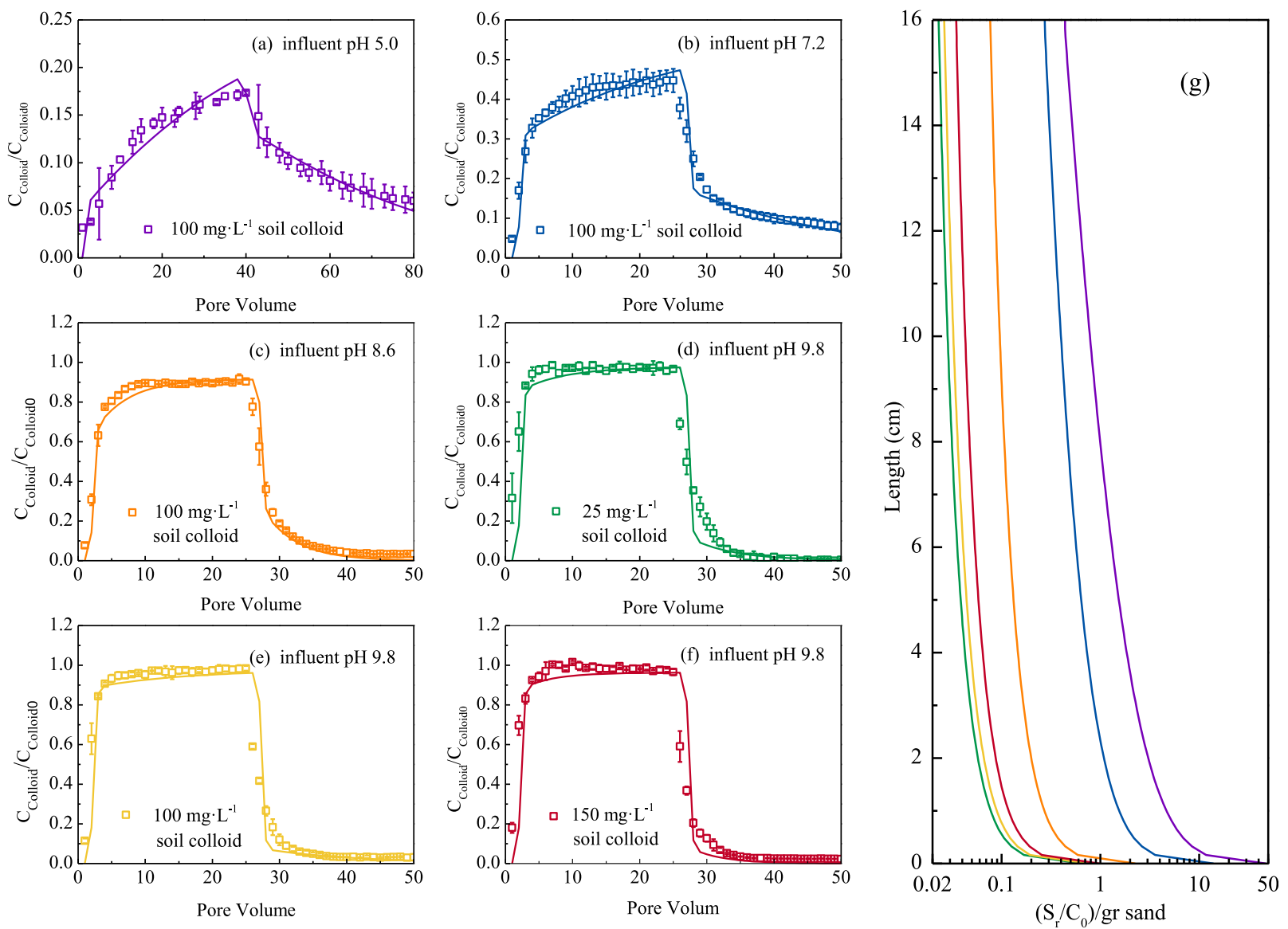

$$
\begin{aligned}
& \text { Legend of g: —influent } \mathrm{pH} 5.0 \text { with } 100 \mathrm{mg} \cdot \mathrm{L}^{-1} \text { soil colloid } \quad \text { - influent } \mathrm{pH} 7.2 \text { with } 100 \mathrm{mg} \cdot \mathrm{L}^{-1} \text { soil colloid } \\
& \text { influent } \mathrm{pH} 8.6 \text { with } 100 \mathrm{mg} \cdot \mathrm{L}^{-1} \text { soil colloid — influent } \mathrm{pH} 9.8 \text { with } 25 \mathrm{mg} \cdot \mathrm{L}^{-1} \text { soil colloid } \\
& \text { — influent } \mathrm{pH} 9.8 \text { with } 100 \mathrm{mg} \cdot \mathrm{L}^{-1} \text { soil colloid — influent } \mathrm{pH} 9.8 \text { with } 150 \mathrm{mg} \cdot \mathrm{L}^{-1} \text { soil colloid }
\end{aligned}
$$

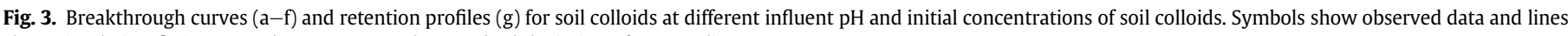
show simulation fitting. Error bars represent the standard deviation of two replicates.

\begin{tabular}{|c|c|c|c|c|c|c|c|}
\hline Influent & Soil colloid recovery ${ }^{\mathrm{a}}(\%)$ & $\mathrm{k}_{1 \mathrm{a}} \mathrm{b}^{\mathrm{b}} \times 10^{3}\left(\mathrm{~min}^{-1}\right)$ & $\mathrm{k}_{1 \mathrm{~d}}{ }^{\mathrm{c}} \times 10^{3}\left(\mathrm{~min}^{-1}\right)$ & $\mathrm{k}_{2 \mathrm{a}}{ }^{\mathrm{d}} \times 10^{2}\left(\mathrm{~min}^{-1}\right)$ & $\mathrm{k}_{1 \mathrm{~d}} / \mathrm{k}_{1 \mathrm{a}}$ & $\mathrm{S}_{\max 1}^{\mathrm{e}} \times 10^{-6}$ & $\mathrm{r}^{2 \mathrm{f}}$ \\
\hline pH 5.0 with $100 \mathrm{mg} \mathrm{L}^{-1}$ soil colloids & $13.0 \pm 0.3$ & $17 \pm 0.73$ & $1.4 \pm 0.21$ & $21 \pm 2.3$ & $0.084 \pm 0.016$ & $4.7 \pm 4.9$ & 0.91 \\
\hline pH 7.2 with $100 \mathrm{mg} \mathrm{L}^{-1}$ soil colloids & $36.8 \pm 1.5$ & $6.4 \pm 0.28$ & $1.4 \pm 0.13$ & $8.8 \pm 0.82$ & $0.21 \pm 0.011$ & $2.5 \pm 2.4$ & 0.96 \\
\hline pH 8.6 with $100 \mathrm{mg} \mathrm{L}^{-1}$ soil colloids & $79.2 \pm 1.4$ & $3.5 \pm 0.14$ & $5.7 \pm 0.94$ & $1.4 \pm 0.36$ & $1.6 \pm 0.20$ & $2.4 \pm 3.3$ & 0.98 \\
\hline pH 9.8 with $25 \mathrm{mg} \mathrm{L}^{-1}$ soil colloids & $93.0 \pm 0.6$ & $1.9 \pm 0.59$ & $5.8 \pm 1.1$ & $0.39 \pm 0.10$ & $3.1 \pm 0.41$ & $2.8 \pm 0.28$ & 0.94 \\
\hline pH 9.8 with $100 \mathrm{mg} \mathrm{L}^{-1}$ soil colloids & $87.4 \pm 1.1$ & $1.1 \pm 0.24$ & $2.4 \pm 0.75$ & $0.45 \pm 0.23$ & $2.2 \pm 0.22$ & $1.4 \pm 0.04$ & 0.94 \\
\hline pH 9.8 with $150 \mathrm{mg} \mathrm{L}^{-1}$ soil colloids & $91.4 \pm 0.1$ & $0.93 \pm 0.13$ & $5.4 \pm 1.3$ & $0.59 \pm 0.08$ & $5.8 \pm 0.57$ & $1.7 \pm 0.34$ & 0.94 \\
\hline
\end{tabular}

Table 2

Fitted parameters of soil colloid transport in columns to the two-kinetic site model (particle transport using attachment/detachment, chemical nonequilibrium).

a Soil colloid recovery in the effluent when the influent was switched from $\mathrm{As}(\mathrm{V})$-soil colloid solutions to Milli-Q water.

b The first-order retention coefficient on Site- $1_{\text {colloid. }}$

c The first-order detachment coefficient on Site- $1_{\text {colloid. }}$.

d The first-order retention coefficient on Site- $2_{\text {colloid. }}$.

e Maximum solid phase concentration of soil colloids on Site- $1_{\text {colloid }}$.

f Squared Person's correlation coefficient.

drastically decreased and was equivalent to adsorption-facilitated kaolinite colloid transport (Saiers and Hornberger, 1999).

Soil colloid transport was enhanced with decreasing soil colloid concentration due to low ionic strength, since the soil colloid was contributing to the ionic strength. However, promoted $\mathrm{As}(\mathrm{V})$ transport increased with increasing soil colloid concentration at $\mathrm{pH}$ 9.8, although a high ionic strength was associated with a high concentration of soil colloid. According to the DLVO theory (Feriancikova and Xu, 2012; Wu et al., 2013), when the colloids approached the surface of porous media, the electric double layer repulsion would prevent colloids from landing on the surface of porous media at a certain $\mathrm{pH}$ ( $\mathrm{pH} 9.8$ in this study), and thus colloidal transport was active in porous media. Based on this investigation, the hypothesis was developed and shown in Fig. 5. Arsenic $(\mathrm{V})$ transport was positively affected by rapid colloidal transport. At $\mathrm{pH}$ 9.8, during $\mathrm{As}(\mathrm{V})$ transport from solution to sand, the moving paths of $\mathrm{As}(\mathrm{V})$ were blocked by the rapid colloidal transport, where the mobile soil colloids readily collided with $\mathrm{As}(\mathrm{V})$ 

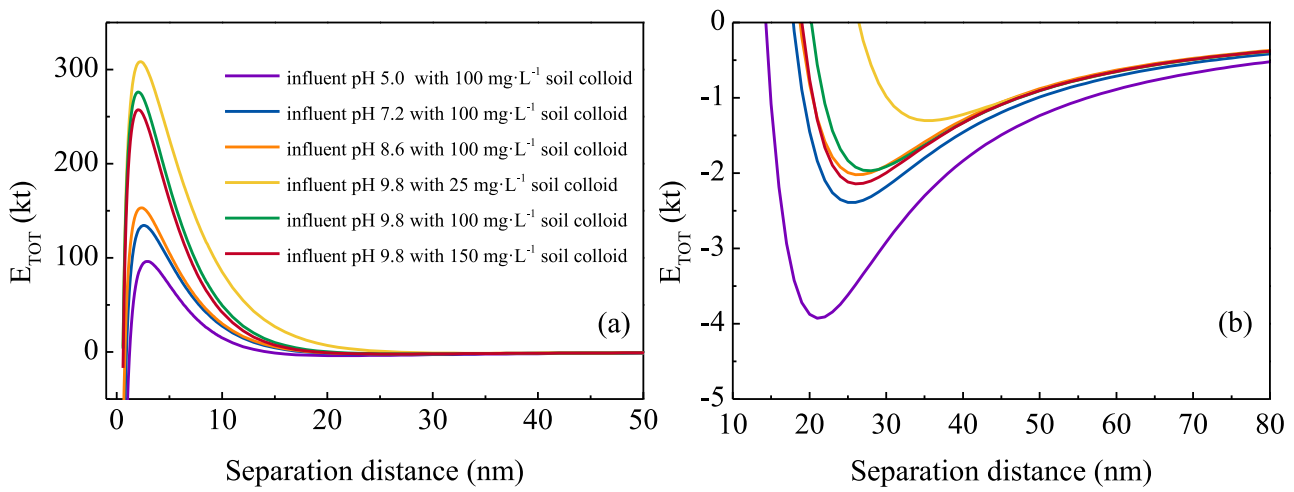

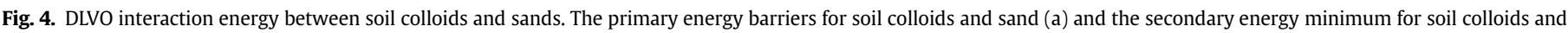
sand (b). The interaction energy was expressed in $\mathrm{kT}$, where $\mathrm{k}$ is the Boltzmann constant, and $\mathrm{T}$ is absolute temperature in Kelvin.

and retarded the $\mathrm{As}(\mathrm{V})$ arriving to the sand surface (Fig. 5). The collision should effectively change the transport direction of $\mathrm{As}(\mathrm{V})$. However, at pH 5.0, 7.2, and 8.6, soil colloid deposition caused $\mathrm{As}(\mathrm{V})$ and soil colloid to move in one direction toward sands, leading to the inefficient collision, whereas at $\mathrm{pH} 9.8, \mathrm{As}(\mathrm{V})$ hardly crossed the "highway of soil colloid" to be adsorbed onto sand due to limited soil colloid deposition (Fig. 5). The phenomenon would be more significant with higher soil colloid concentrations. The blocking effect of soil colloid on $\mathrm{As}(\mathrm{V})$ retention onto sand decreased $\mathrm{As}(\mathrm{V})$ adsorption on both instantaneous and first-order kinetic sites, and therefore promoted $\mathrm{As}(\mathrm{V})$ transport in the porous media.

\section{Conclusions}

As the third phase except for stationary phase (consisting of subsurface solids) and the mobile aqueous phase (as the medium for the movement of dissolved chemical species), colloids can increase the apparent solubility of low-soluble pollutants and thus facilitate transport of those pollutants, which greatly improves the mobility of pollutants (Kretzschmar and Schafer, 2005). Our study extended this current theory, by showing that the presence of soil colloids with low $\operatorname{As}(\mathrm{V})$ adsorption capacity accelerated $\operatorname{As}(\mathrm{V})$ transport in porous media. Results show that strong repulsion between porous media and soil colloids led to soil colloid-promoted $\mathrm{As}(\mathrm{V})$ transport by blocking $\mathrm{As}(\mathrm{V})$ adsorption onto porous media. They indicate that colloids can play an important role in facilitating solute transport, not only as a carrier in the course of solute transport but also as a barrier in the course of solute adsorption. The blocking effect of colloid should be ubiquitous in natural aqueous environments, with similar colloid concentrations to this study between 1 and $60 \mathrm{mg} \mathrm{L}^{-1}$ in groundwater (Ronen et al., 1992; Ryan and Gschwend, 1990) and the strong steric repulsion of colloids at normal pH, such as montmorillonite colloid (Shen et al., 2015) and kaolinite colloid (Saiers and Hornberger, 1996). This finding provides a new insight into colloid-facilitated transport, especially for colloids with low adsorption capacity for pollutants, in complex soil and groundwater systems, such as surface water infiltration systems, and hyporheic zones with intensive interaction between surface water and groundwater. Future investigation will evaluate the effects of flow rate, geometry of colloid-systems, type of porous media, and type of colloid, especially inert microspheres to eliminate complicated interaction between soil colloids and

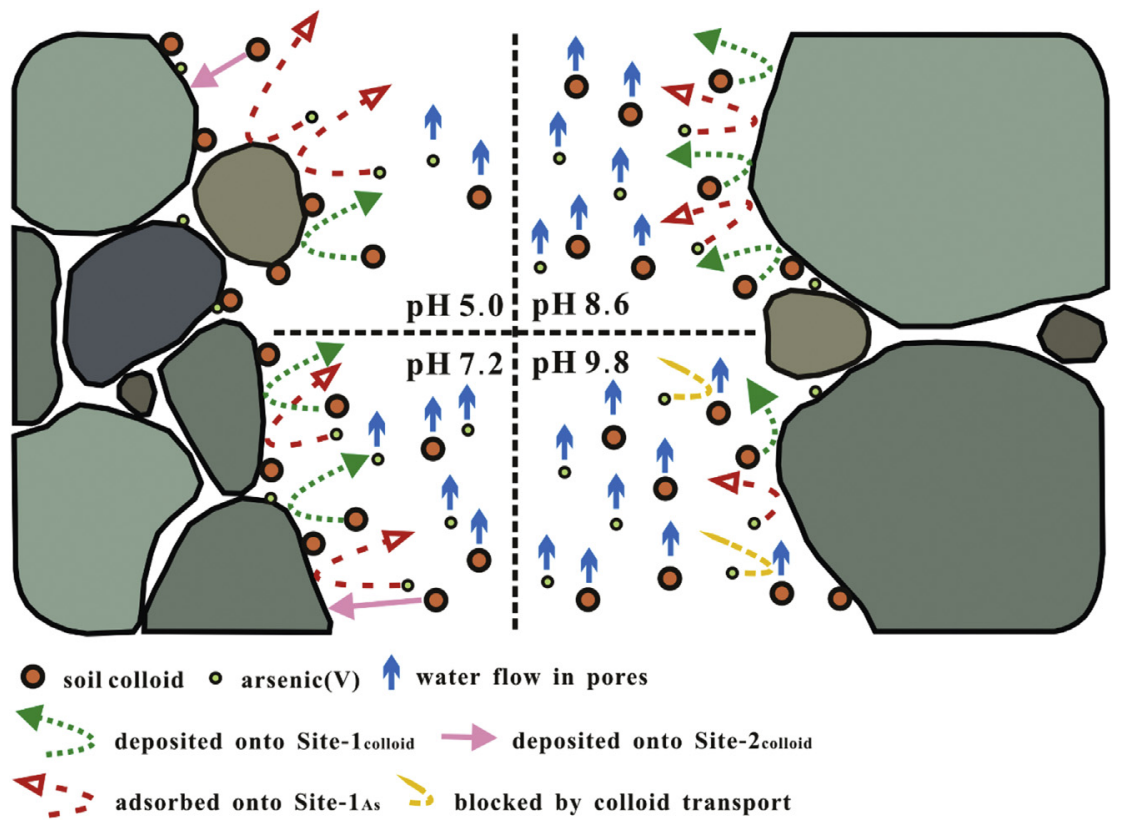

Fig. 5. Hypothetic diagram of blocking effect of soil colloid on $\mathrm{As}(\mathrm{V})$ adsorption onto sand during co-transport. 
porous media, on colloid-promoted solute transport.

\section{Acknowledgments}

The study is financially supported by the National Natural Science Foundation of China (Nos. 41222020 and 41172224), the Fundamental Research Funds for the Central Universities (Nos. 2652013028 and 2652014094), and the Fok Ying-Tung Education Foundation, China (Grant No. 131017).

\section{Appendix A. Supplementary data}

Supplementary data related to this article can be found at http:// dx.doi.org/10.1016/j.envpol.2016.03.020.

\section{References}

Adamczyk, Z., Siwek, B., Zembala, M., Belouschek, P., 1994. Kinetics of localized adsorption of colloid particles. Adv. Colloid Interface Sci. 48, 151-280.

Asta, M.P., Cama, J., Martinez, M., Gimenez, J., 2009. Arsenic removal by goethite and jarosite in acidic conditions and its environmental implications. J. Hazard. Mater 171, 965-972.

Bauer, M., Blodau, C., 2009. Arsenic distribution in the dissolved, colloidal and particulate size fraction of experimental solutions rich in dissolved organic matter and ferric iron. Geochim. Cosmochim. Ac 73, 529-542.

Bradford, S.A., Bettahar, M., 2006. Concentration dependent transport of colloids in saturated porous media. J. Contam. Hydrol. 82, 99-117.

Bradford, S.A., Simunek, J., Bettahar, M., Van Genuchten, M.T., Yates, S.R., 2003. Modeling colloid attachment, straining, and exclusion in saturated porous media. Environ. Sci. Technol. 37, 2242-2250.

Cameron, D.R., Klute, A., 1977. Convective-dispersive solute transport with a combined equilibrium and kinetic adsorption model. Water Resour. Res. 13, 183-188.

Charlet, L., Morin, G., Rose, J., Wang, Y., Auffan, M., Burnol, A., FernandezMartinez, A., 2011. Reactivity at (nano)particle-water interfaces, redox processes, and arsenic transport in the environment. CR Geosci. 343, 123-139.

Denaix, L., Semlali, R.M., Douay, F., 2001. Dissolved and colloidal transport of Cd, Pb, and $\mathrm{Zn}$ in a silt loam soil affected by atmospheric industrial deposition. Environ. Pollut. 114, 29-38.

Derjaguin, B., Landau, L., 1941. Theory of the stability of strongly charged lyophobic sols and of the adhension of strongly charged particles in solutions of electrolytes. Acta Physicochim. USSR 14, 733-762.

Dousova, B., Buzek, F., Rothwell, J., Krejcova, S., Lhotka, M., 2012. Adsorption behavior of arsenic relating to different natural solids: soils, stream sediments and peats. Sci. Total Environ. 433, 456-461.

Feriancikova, L., Bardy, S.L., Wang, L., Li, J., Xu, S., 2013. Effects of outer membrane protein TolC on the transport of Escherichia coli within saturated quartz sands. Environ. Sci. Technol. 47, 5720-5728.

Feriancikova, L., Xu, S., 2012. Deposition and remobilization of graphene oxide within saturated sand packs. J. Hazard. Mater 235-236, 194-200.

Fritzsche, A., Rennert, T., Totsche, K.U., 2011. Arsenic strongly associates with ferrihydrite colloids formed in a soil effluent. Environ. Pollut. 159, 1398-1405.

Grolimund, D., Borkovec, M., 2005. Colloid facilitated transport of strongly sorbing contaminants in natural porous media: mathematical modeling and laboratory column experiments. Environ. Sci. Technol. 39, 6378-6386.

Grolimund, D., Borkovec, M., Barmettler, K., Sticher, H., 1996. Colloid-facilitated transport of strongly sorbing contaminants in natural porous media: a laboratory column study. Environ. Sci. Technol. 30, 3118-3123.

Guo, H., Li, Y., Zhao, K., 2010. Arsenate removal from aqueous solution using synthetic siderite. J. Hazard. Mater 176, 174-180.

Guo, H., Wen, D., Liu, Z., Jia, Y., Guo, Q., 2014. A review of high arsenic groundwater in Mainland and Taiwan, China: distribution, characteristics and geochemical processes. Appl. Geochem 41, 196-217.

Guo, H., Zhang, B., Zhang, Y., 2011. Control of organic and iron colloids on arsenic partition and transport in high arsenic groundwaters in the Hetao basin. Inn. Mong. Appl. Geochem 26, 360-370.

Hammes, J., Gallego-Urrea, J.A., Hassellov, M., 2013. Geographically distributed classification of surface water chemical parameters influencing fate and behavior of nanoparticles and colloid facilitated contaminant transport. Water Res. 47, 5350-5361.

Honeyman, B.D., 1999. Geochemistry - colloidal culprits in contamination. Nature $397,23-24$.

Jellali, S., Diamantopoulos, E., Kallali, H., Bennaceur, S., Anane, M., Jedidi, N., 2010. Dynamic sorption of ammonium by sandy soil in fixed bed columns: evaluation of equilibrium and non-equilibrium transport processes. J. Environ. Manage 91, 897-905.

Jessen, S., Larsen, F., Koch, C.B., Arvin, E., 2005. Sorption and desorption of arsenic to Ferrihydrite in a sand filter. Environ. Sci. Technol. 39, 8045-8051.

Kanti Sen, T., Khilar, K.C., 2006. Review on subsurface colloids and colloidassociated contaminant transport in saturated porous media. Adv. Colloid
Interface Sci. 119, 71-96.

Kersting, A.B., Efurd, D.W., Finnegan, D.L., Rokop, D.J. Smith, D.K., Thompson, J.L. 1999. Migration of plutonium in ground water at the Nevada Test Site. Nature $397,56-59$

Kretzschmar, R., Schafer, T., 2005. Metal retention and transport on colloidal particles in the environment. Elements 1, 205-210.

Liang, Q., Zhao, D., 2014. Immobilization of arsenate in a sandy loam soil using starch-stabilized magnetite nanoparticles. J. Hazard. Mater 271, 16-23.

Liang, Y., Bradford, S.A., Simunek, J., Vereecken, H., Klumpp, E., 2013. Sensitivity of the transport and retention of stabilized silver nanoparticles to physicochemical factors. Water Res. 47, 2572-2582.

Ma, J., Guo, H., Lei, M., Zhou, X., Li, F., Yu, T., Wei, R., Zhang, H., Zhang, X., Wu, Y., 2015a. Arsenic adsorption and its fractions on aquifer sediment: effect of $\mathrm{pH}$, arsenic species, and iron/manganese minerals. Water Air Soil Poll. 226.

Ma, J., Mi, Y., Li, Q., Chen, L., Du, L., He, L., Lei, M., 2016. Reduction, methylation, and translocation of arsenic in Panax notoginseng grown under field conditions in arsenic-contaminated soils. Sci. Total Environ. 550, 893-899.

Ma, S., Zhou, K., Yang, K., Lin, D., 2015b. Heteroagglomeration of oxide nanoparticles with algal cells: effects of particle type, ionic strength and pH. Environ. Sci. Technol. 49, 932-939.

Marquardt, D.W., 1963. An algorithm for least-squares estimation of nonlinear parameters. J. Soc. Ind. Appl. Math. 11, 431-441.

Neubauer, E., von der Kammer, F., Knorr, K.H., Peiffer, S., Reichert, M., Hofmann, T. 2013. Colloid-associated export of arsenic in stream water during stormflow events. Chem. Geol. 352, 81-91.

Pedrot, M., Dia, A., Davranche, M., Bouhnik-Le Coz, M., Henin, O., Gruau, G., 2008. Insights into colloid-mediated trace element release at the soil/water interface. J. Colloid Interface Sci. 325, 187-197.

Qiao, J., Jiang, Z., Sun, B., Sun, Y., Wang, Q., Guan, X., 2012. Arsenate and arsenite removal by $\mathrm{FeCl}_{3}$ : effects of $\mathrm{pH}$, As/Fe ratio, initial As concentration and coexisting solutes. Sep. Purif. Technol. 92, 106-114.

Ronen, D., Magaritz, M., Weber, U., Amiel, A.J., Klein, E., 1992. Characterization of suspended particles collected in groundwater under natural gradient flow conditions. Water Resour. Res. 28, 1279-1291.

Roy, S.B., Dzombak, D.A., 1997. Chemical factors influencing colloid-facilitated transport of contaminants in porous media. Environ. Sci. Technol. 31, 656-664.

Ryan, J.N., Elimelech, M., 1996. Colloid mobilization and transport in groundwater Colloid. Surf. A 107, 1-56.

Ryan, J.N., Gschwend, P.M., 1990. Colloid mobilization in two Atlantic coastal plain aquifers: field studies. Water Resour. Res. 26, 307-322.

Saiers, J.E., 2002. Laboratory observations and mathematical modeling of colloidfacilitated contaminant transport in chemically heterogeneous systems. Water Resour. Res. 38, 3-1-3-13.

Saiers, J.E., Hornberger, G.M., 1996. The role of colloidal kaolinite in the transport of cesium through laboratory sand columns. Water Resour. Res. 32, 33-41.

Saiers, J.E., Hornberger, G.M., 1999. The influence of ionic strength on the facilitated transport of cesium by kaolinite colloids. Water Resour. Res. 35, 1713-1727.

Selim, H.M., Davidson, J.M., Mansell, R.S., 1976. Evaluation of a two-site adsorption-desorption model for describing solute transport in soils. In: Proc. Summer Computer Simulation Conf., Washington, D.C.

Shani, C. Weisbrod, N. Yakirevich, A, 2008. Colloid transport through saturated sand columns: influence of physical and chemical surface properties on deposition. Colloid. Surf. A 316, 142-150.

Shen, C., Wang, H., Lazouskaya, V., Du, Y., Lu, W., Wu, J., Zhang, H., Huang, Y., 2015 Cotransport of bismerthiazol and montmorillonite colloids in saturated porous media. J. Contam. Hydrol. 177-178, 18-29.

Simunek, J., He, C.M., Pang, L.P., Bradford, S.A., 2006. Colloid-facilitated solute transport in variably saturated porous media: numerical model and experimental verification. Vadose Zone J. 5, 1035-1047.

Slowey, A.J., Johnson, S.B., Newville, M., Brown, G.E., 2007. Speciation and colloid transport of arsenic from mine tailings. Appl. Geochem 22, 1884-1898.

Sun, P., Shijirbaatar, A., Fang, J., Owens, G., Lin, D., Zhang, K., 2015a. Distinguishable transport behavior of zinc oxide nanoparticles in silica sand and soil columns. Sci. Total Environ. 505, 189-198.

Sun, Y., Gao, B., Bradford, S.A., Wu, L., Chen, H., Shi, X., Wu, J., 2015b. Transport, retention, and size perturbation of graphene oxide in saturated porous media: effects of input concentration and grain size. Water Res. 68, 24-33.

Toride, N., Leij, F.J., van Genuchten, M. Th, 1999. The CXTFIT Code for Estimating Transport Parameters from Laboratory or Field Tracer Experiments, Version 2.1. Res. Rep. No. 137. U.S. Salinity Laboratory, Riverside, CA.

Verwey, E.J.M., Overbeek, J.T.G., 1948. Theory of the Stability of Lyophobic Colloids. Elsevier, Amsterdam.

Wan, J., Tokunaga, T.K., 2002. Partitioning of clay colloids at air-water interfaces J. Colloid Interface Sci. 247, 54-61.

Wang, D., Bradford, S.A., Harvey, R.W., Gao, B., Cang, L., Zhou, D., 2012. Humic acid facilitates the transport of ARS-labeled hydroxyapatite nanoparticles in iron oxyhydroxide-coated sand. Environ. Sci. Technol. 46, 2738-2745.

Wang, D., Paradelo, M., Bradford, S.A., Peijnenburg, W.J., Chu, L., Zhou, D., 2011a Facilitated transport of Cu with hydroxyapatite nanoparticles in saturated sand: effects of solution ionic strength and composition. Water Res. 45, 5905-5915.

Wang, D., Zhang, W., Zhou, D., 2013. Antagonistic effects of humic acid and iron oxyhydroxide grain-coating on biochar nanoparticle transport in saturated sand. Environ. Sci. Technol. 47, 5154-5161.

Wang, L., Xu, S., Li, J., 2011b. Effects of phosphate on the transport of Escherichia col 0157:H7 in saturated quartz sand. Environ. Sci. Technol. 45, 9566-9573. 
Wang, Q., Cheng, T., Wu, Y., 2014. Influence of mineral colloids and humic substances on uranium(VI) transport in water-saturated geologic porous media. J. Contam. Hydrol. 170, 76-85.

Wu, L., Liu, L., Gao, B., Munoz-Carpena, R., Zhang, M., Chen, H., Zhou, Z., Wang, H., 2013. Aggregation kinetics of graphene oxides in aqueous solutions: experiments, mechanisms, and modeling. Langmuir 29, 15174-15181.

Yin, X., Gao, B., Ma, L.Q., Saha, U.K., Sun, H., Wang, G., 2010. Colloid-facilitated Pb transport in two shooting-range soils in Florida. J. Hazard. Mater 177, 620-625. Zhang, M., Li, W., Yang, Y., Chen, B., Song, F., 2005. Effects of readily dispersible colloid on adsorption and transport of $\mathrm{Zn}, \mathrm{Cu}$, and $\mathrm{Pb}$ in soils. Environ. Int. 31, 840-844.

Zou, Y., Zheng, W., 2013. Modeling manure colloid-facilitated transport of the weakly hydrophobic antibiotic florfenicol in saturated soil columns. Environ. Sci. Technol. 47, 5185-5192. 